\title{
Service to the South African society through prophetic testimony as a liturgical act
}

\begin{tabular}{|c|c|}
\hline \multicolumn{2}{|c|}{$\begin{array}{l}\text { Author: } \\
\text { Ben J. de Klerk }{ }^{1}\end{array}$} \\
\hline $\begin{array}{l}\text { Affiliation: } \\
{ }^{1} \text { Faculty of Th } \\
\text { North-West U } \\
\text { Potchefstroor } \\
\text { South Africa }\end{array}$ & $\begin{array}{l}\text { eology, } \\
\text { niversity, } \\
\text { Campus, }\end{array}$ \\
\hline $\begin{array}{l}\text { Note: } \\
\text { This article is } \\
\text { section Practi } \\
\text { of the Society } \\
\text { Theology in S }\end{array}$ & $\begin{array}{l}\text { oublished in the } \\
\text { cal Theology } \\
\text { for Practical } \\
\text { outh Africa. }\end{array}$ \\
\hline $\begin{array}{l}\text { This article wa } \\
\text { paper deliver } \\
\text { meeting of th } \\
\text { for Practical T } \\
\text { Potchefstroon } \\
\text { January } 2013 \text {. } \\
\text { of the confere } \\
\text { 'Practical thec } \\
\text { service delive }\end{array}$ & $\begin{array}{l}\text { s initially a } \\
\text { d at the annual } \\
\text { Society } \\
\text { heology in } \\
\text { n, 23th - 25th } \\
\text { The theme } \\
\text { nce: } \\
\text { logy and } \\
\text { ry'. }\end{array}$ \\
\hline $\begin{array}{l}\text { Corresponder } \\
\text { Ben de Klerk }\end{array}$ & ice to: \\
\hline $\begin{array}{l}\text { Email: } \\
\text { ben.deklerk@ }\end{array}$ & nwu.ac.za \\
\hline $\begin{array}{l}\text { Postal addres } \\
\text { PO Box } 20764 \\
2522 \text {, South A }\end{array}$ & $\begin{array}{l}\text { S: } \\
\text { Noordbrug } \\
\text { frica }\end{array}$ \\
\hline $\begin{array}{l}\text { Dates: } \\
\text { Received: } 14 \\
\text { Accepted: } 04 \\
\text { Published: } 31\end{array}$ & $\begin{array}{l}\text { Apr. } 2013 \\
\text { May } 2013\end{array}$ \\
\hline $\begin{array}{l}\text { How to cite th } \\
\text { De Klerk, B.J., } \\
\text { to the South A } \\
\text { society throug } \\
\text { testimony as } \\
\text { act', HTS Teolo } \\
\text { Theological St } \\
\text { Art. \#1941, } 9 \\
\text { http://dx.doi. } \\
\text { hts.v69i2.194 }\end{array}$ & $\begin{array}{l}\text { is article: } \\
\text { 2013, 'Service } \\
\text { frican } \\
\text { h prophetic } \\
\text { liturgical } \\
\text { giese Studies/ } \\
\text { udies 69(2), } \\
\text { pages. } \\
\text { org/10.4102/ } \\
1\end{array}$ \\
\hline $\begin{array}{l}\text { Copyright: } \\
\text { C 2013. The A } \\
\text { Licensee: AOS } \\
\text { OpenJournals } \\
\text { is licensed unc } \\
\text { Creative Comr } \\
\text { Attribution Lic }\end{array}$ & $\begin{array}{l}\text { Authors. } \\
\text { IS } \\
\text { This work } \\
\text { der the } \\
\text { nons } \\
\text { ense. }\end{array}$ \\
\hline Read online: & $\begin{array}{l}\text { Scan this QR } \\
\text { code with your } \\
\text { smart phone or } \\
\text { mobile device } \\
\text { to read online. }\end{array}$ \\
\hline
\end{tabular}

It is suggested that a clear prophetic voice of the congregational gathering could change the society to which the congregants belong. The problem is that this prophetic voice seems to have disappeared in many cases. A solution might be found if the point of view is taken that the prophetic voice in the congregational gathering is heard in the liturgical acts or rites. In the science of Liturgy attention must be given to the revitalisation of the gift of prophesy. In this article the prophetic testimony of the Old Testament prophets and of the Prophet, Jesus Christ, were used as sources. Following in the footsteps of Brueggemann, an effort will be made to establish in relevant scripture passages what the attitude and practise of prophetic testimony should be. The possibility of rendering service through prophetic testimony as a liturgical act in the South African society is wide open. Prophetic testimony serves to criticise the dominant perception in order to dismantle it, but is also serves to energise persons and communities by its promise of another time and situation towards which the community of faith could move.

\section{Introduction}

A society that has to address social problems such as corruption, unemployment, poverty, inequality, poor education and labour unrest is in desperate need of prophets. In this article, it is suggested that the clear prophetic voice of the congregational gathering could change the society to which the congregants belong. The problem is that this prophetic voice seems to have disappeared in many cases.

A solution might be found from the point of view that the prophetic voice in the congregational gathering is heard in the liturgical acts or rites. Liturgical acts focus on the meeting of God with his people, the congregation with God and congregants with one another. The worship service is also a public service, directed at the world in which worshippers live. The purpose of the acts in the worship service is to equip believers to continue their worship in everyday life in the society where God places them. It is assumed that liturgical acts or rites have the power and the striking force to give a strong prophetical testimony, not only in the gathering of the congregants, but also in their society. The liturgical act that is eminently suited to carry out the prophetic voice, but what is rarely found in congregational gatherings is the gift of prophecy.

The following issues will now be investigated: What is the gift of prophecy and what are the guidelines for performing the gift of prophecy or giving prophetic testimony in a society, specifically the South African society? How can the participants in the worship service be equipped to give testimony in a society in which the education system is deteriorating and labour unrest is increasing?

The work plan is first to investigate the gift of prophecy from the perspective of the 16th century Reformation. The next step is to show that prophetic testimony is grounded in Old Testament prophecies and the prophetic work of Jesus. Subsequently, the act of performing the gift of prophecy in present-day society is explained. Finally, the giving of prophetic testimony in society is briefly applied to two examples, the burning questions in the South African society today, namely education and labour unrest.

The research is conducted mainly by means of a critical literature study and by suggesting how relevant findings could be put into practice.

\section{The gift of prophecy}

The gift of prophecy goes back to the 16th century prophecy, which originated in Zürich. The content of 1 Corinthians 14, which concerns the gift of prophecy, was decisive for the practical application of scripture reading and preaching in the life of the church in those times. Zwingli was disputing the hierarchy of the so-called Armenians, who based their doctrine mainly on 
1 Corinthians $14 .{ }^{1}$ He argued that the gift of prophecy did not point to a new revelation alongside scripture, but that it referred in the first place to knowledge of Hebrew and Greek, and secondly, that it emphasised the explanation and application of scripture. After the preacher - who understood the original languages - had explained and applied the passage of scripture, the members of the congregation could avail themselves of the opportunity to make further applications, the so called 'gift of prophecy'. The Genevan congregation was one of the branches that sprung from the roots of the Prophezei, which was instituted in 1525 in Zürich and dedicated to the study of the Bible. ${ }^{2}$

We are reminded that the 16th century Reformation also sought a missionary target for the church service: the sermon was exemplified as publice docere - public education - where members could apply the word (cf. Calvin, Inst. IV.I.19) (Barnard \& Wepener 2012:3). The practice gained new momentum in the congregations under the leadership of A. Lasco. Together with Marten Micron, Lasco testified to the practice in their respective church orders (De Boer 2004:652). Voetius fought to reinstate the gift of prophecy in the second half of the 17th century, and Labadie supported the prophecy in word and deed. During the Reformation, there was an emphasis to return the knowledge and interpretation of scripture to the hands of the common people (Farnell 1992:296). From the work of the reformers, especially John Knox, the following conclusion may be made: the 16th century prophecy is the joint investigation of scripture by congregants with a special gift to apply the preached Word to concrete situations (Du Toit 1977:79). Based on the gift of prophecy the 1568 Synod of Wesel stated that members who eagerly desired the gift that God gave them, had to utilise it in the interest of their communities.

How can prophecy be defined? Traditionally viewed, biblical prophecy is 'inspired utterance' that stems from a direct revelation of God. The viewpoint that prophecy has different levels is difficult to support biblically. With this in mind, it is said that the utterances range from messages that consist totally of God's Word and therefore they are inerrant, to

1.The 'gift of prophecy' in 1 Corinthians 14 is a different phrase than the office of prophecy as used in Ephesians 4 verse 11 ( cov̀ $\delta \dot{\varepsilon} \pi \rho 0 \varphi \eta \tau \alpha \varsigma)$. In the Ephesians text $\pi \rho \varphi^{\prime} \tau \alpha \varsigma$ is a noun (a sort of status). In 1 Corintians 14 Paul describes some of the

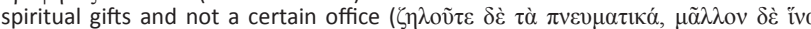
$\pi \rho \circ \emptyset \eta \tau \varepsilon \dot{\eta} \eta \varepsilon)$ : In 1 Corinthians 14 'prophecy' is used as a verb. Zwingli referred to this passage of scripture. In this article my argument is not to reinstate the office of the prophets, but that all believers $(\pi \rho 0 \varphi \eta \tau \varepsilon v ́ \eta \tau \varepsilon)$ you will eagerly desire to of the prophesy (and not specific people in an 'office' of prophecy).
prophes 2.The idea of regular biblical studies was probably brought to Geneva by Guillaume
Farel. In France, Jean Morely advocated a democratic form of church government in his Traité de la discipline et police Chretienne of 1562. Consequently, all members in his Traite de la discipline et police Chretienne of 1562 . Consequently, all members
of the congregation were to participate in the biblical study groups. This was a veiled critique of the predominance of the pastors in the congregation in Geneva. The church of the Dutch refugees in London organised a more democratic form of biblical study meetings. In those meetings, the lay members played a more active role. They commented on the sermon of the previous Sunday and could raise questions on any subject. In the London church of the French refugees, the biblical studies resembled the Genevan congregations (De Boer 2004:652). In Genève, on every Friday, a conference was held in the largest church and all the ministers and many of the members participated. One of them read a passage from scripture and expounded it briefly. Another would tell about the matter that he deemed to be according to the Spirit. A third person ave his opinion and a fourth added to be according to the Spirt. A third person gave his opinion and a fourth added some matters according to his capacity to contribute to the issue. Not only did the ministers act thus, but everyone who had come to listen (De Boer 2004:655). In th way, they followed what Paul found in the church of Corinth. Paul said that when the brothers gathered everyone could say what the Spirit revealed to him. Then such a person had to be silent and sit down, and another could begin to speak (cf. 1 Cor 14:29-30). messages that are mixed with varying degrees of human thought and therefore they include error. The view that prophesying is the function of the prophet is foundational to the church, but some scholars regard it as a thing of the past (see Harold 2003:168). Is prophecy tantamount to the utterance of mysteries (1 Cor 13:12) and of enigmatic riddles? No. Is prophecy a special temporary ability to bring a word, a warning, exhortation or revelation from God under the impulse of the Holy Spirit? No. If this had been true, the prophet and his function would altogether have ceased to exist. The offices of apostles and prophets (see Eph 4:11) were foundational in the sense that they were intrinsically tied to the giving of the New Testament message. The Apostles and Prophets laid the foundation of the church with their teaching, but the time of the Apostles and New Testament's Prophets has passed (1 Cor 1, 17; 1 Cor 3, 6, 10). For this reason, Christ gives the gift of prophesy to his church.

What is the gift of prophecy? Prophecy in the sense of 1 Corinthians 14 is not to forecast future things, but to interpret scripture concretely and to apply the interpretation in consoling and admonishing the congregation and society (Hall 2003:144). Prophecy is above all the gift to understand and express what the will of God is in a concrete, given situation (Ac 11, 28; 13, 1; 15, 32).

By using this gift the church can explain what God has done and is still doing, as well as what his commands and expectations are for every congregation and member. In practice, it means that the insight of people into the Word of God is used to console and encourage the congregation by revealing God's governance of them (Green 2002:265). By means of prophecy, the helping hand of God is extended directly to the congregants (Cranfield 2004:620). In this way, the congregation receives the guidance of God in their practical lives.

As prophecy is applied to build up the congregation, the congregation must make special room for the prophetic word in the worship service (1 Cor 14, 39; cf. Rm 12, 6, 7; 1 Th 5, 20). The church should long for authentic prophetic preaching. As the gift of prophecy is closely related to the work of the Holy Spirit and preaching, it should be exercised in the first place within the frame of the worship service (1 Cor 11, 17-14, 39). The importance of the gift of prophecy is emphasised by Calvin (1965:269), who was of the opinion that the gift of prophesy could not be limited to the 1st century, the birth of the Christian Church. His view further affirms that prophesy is the correct understanding of a scripture passage and the gift to explain and apply it to the present congregation.

\section{Prophetic testimony grounded in the prophecies of the Old Testament prophets and of Jesus}

Another issue that arises from the preceding discussion is the attitude with which the gift of prophecy must be performed. Frequently, the viewpoint has been and still is, that prophetic testimony consists only of harsh confrontation 
and condemnation of some of the problems facing a society, for example the poor education system and the escalation of labour unrest in South Africa. The question is where can the prophets of today find inspiration to give voice to their prophetic gift? In this article the prophetic testimony of the Old Testament prophets and of the Prophet Jesus Christ, will be used as sources. Following in the footsteps of Brueggemann $(2001,2011)$, an effort will be made to establish in relevant scripture passages what the attitude and practising of prophetic testimony should be.

Brueggemann (2011) supports the arguments made in the previous section when he explains:

The prophetic is not, contrary to some conservative views, a matter of prediction. Nor is it, contrary to some liberal views, a nagging or a scolding or righteous indignation about social justice. It is, rather, a sustained effort to imagine the world as though YHWH (God) were a real character and the defining agent in the life of the world. (p. 132)

True prophetic preaching is witnessing, affirmation, proclamation that God is, that God reigns and that God does not abandon or forget. The prophetic tradition proclaims a God who is an active agent, who is manifestly present in the life of the world and who is always up to the business of creating new things. He asks in Isaiah 43:19, 'I am about to do a new thing; do you not perceive it?' Prophetic proclamation is an attempt to imagine the world as though God - the creator of the world, the deliverer of Israel, the Father of our Lord Jesus Christ, whom we Christians come to name as Father, Son and Spirit - were a real character and an effective agent in the world (Brueggemann 2011:2).

Brueggemann (2011) deduces the following from these arguments:

Given my thesis that imagining YHWH as a real character and as an effective agent in the world leads then to a second, derivative thesis: prophetic proclamation is the staging and performance of a contest between two narrative accounts of the world and an effort to show that the YHWH account of reality is more adequate and finally more reliable than the dominant narrative account that is cast among us as though it were true and beyond critique. (p. 3)

He calls the one narrative the YHWH or gospel narrative and the other one the dominant narrative:

The dominant narrative - one I have characterized as 'therapeutic, technological, consumerist militarism' - is committed to the notion of self-invention in the pursuit of self-sufficiency. Between a beginning in self-invention and a culmination in selfsufficiency, that narrative enjoins to competitive productivity, motivated by pervasive anxiety about having enough, or being enough, or being in control. (Brueggemann 2011:4)

The alternative of the dominant narrative is the YHWH (or gospel) narrative that specialises in social transformation, justice, and compassion.

Bruggemann (2011:24) uses the word 'imagination' (the practice of prophetic imagination) not in the sense of unrealistic dreams, but to him imagination is the capacity to generate and enunciate images (imagination) of reality that are not rooted in our perceived world. Through images and metaphors (e.g. Hs 7:11;13:2; Jr 2:13; Is 40:15) the characteristic prophetic utterance intends to shock, evoke, tease, probe with possibility for what has been, until the moment of the prophecy, unthinkable and unsayable.

The question is what the method of the prophets and Jesus would be in the tension between the two abovementioned narratives. Because churches in our society are also marginalised, the old stance of confrontation in a top-down manner is increasingly difficult. Therefore, an alternative in the work of the prophetic literature needs to be found. Prophetic testimony must show more nuances than before. Brueggemann (2001:3) proposes an alternative task of prophetic ministry, namely nurturing, nourishing and evoking a consciousness and perception alternative to the consciousness and perception of the dominant culture around us.

On the one hand, this alternative consciousness serves to criticise the dominant consciousness in order to dismantle it; on the other hand, the alternative consciousness serves to energise persons and communities by its promise of another time and situation towards which the community of faith could move. People in the dominant culture avoid criticism, because it could endanger their so-called safe position. They sheer away from being energised by exciting new possibilities, because the status quo provides them a comfort zone. In this situation, the prophet's eyes are directed at the contemporary scene, while his ears are inclined towards God. An example will illuminate the point. When we are confronted by a growing economy against the background of the enormous wealth and the prosperity in the world, the temptation is to say 'Yes!' to the economic system. However, prophets have a different perspective of reality. They call upon the people to abandon the status quo imposed by those who would profit most from it. A prophet would have the ability to perceive and to point out the specific problems within the bigger picture of an economic system that benefits a few people but victimises the majority (Junler 2011:136).

The work of 21st century prophets is to expose the denial of and identify the infidelities that make our common life toxic. The important thing is to name the losses that are experienced in society, such as a stolen laptop, a husband who has suddenly passed away, loss of income through other's corruption, inequality in income and education and destruction of property during strikes.

In the history of the Old Testament God's people frequently acted against the will of God. The royal group led people into numbness and self-deception that resulted in the death of the nation and exile. There is no doubt that the prophetic theme in the Old Testament is divine judgement, but the punishment was postponed for a long time. During that time, criticism took a remarkable turn. The divine judgement is in fact a subset of the overriding reality of loss. The divine judgement 
is shot through with divine pathos and the pathos of God comes as compassion. God is standing alongside his people in their loss. God also lost his city, the temple, the people and his covenant (Brueggemann 2011:72). The prophets found that God is driven to deep grief for the losses.

Jeremiah is the clearest model of prophetic testimony to criticism by means of grief. He experienced the death of God's people, the Babylonian exile (598 BC) and the fall of Jerusalem (587 BC) very closely. He grieved over the death of his people and their stubborn refusal to listen to the warning that the end was coming. His grief was so intense that he could not cry enough (' $\mathrm{O}$ that my head were waters and my eyes a fountain of tears that I may weep day and night'; Jr 9:1). The crying, the grief, the pain of death - all of these emotions and feelings belong to God.

Jesus understood Jeremiah and proclaimed that only those who mourn will be comforted (Mt 5:4). Only those who embrace the reality of death will receive the new life. Jesus' weeping permits the Kingdom to come (Bruggemann 2001:57). Twenty-first century prophetic testimony has the function to point out the despair and to proclaim the divine resolve that the vicious cycles of self-destruction will be broken and that a general new life will become possible (Bruggemann 2011:38). Despair is the great enemy of hope and brings hopelessness. In this context, it should be remembered that hope must be primarily theological in the covenant language between a personal God and a community. As God's people are invited to grieve the grief of God over the outcome, so his people are invited to put their hope on God's promises. ${ }^{3}$ A promise belongs to the world of trusting speech and faithful listening (Brueggemann 2001:66). The hope-filled language of prophecy by cutting through despair and hopelessness is the language of amazement. The language of amazement is an antidote against despair, just as the language of grief is an antidote against numbness. The language of amazement was the ultimate energiser in Israel, and the prophets were called to use that most energising language in practice (Bruggemann 2001:68). It is especially noticeable during the time of exile. Second Isaiah begins with the song, '[c]omfort my people, says your God. Speak tenderly to Jerusalem and cry to her that her warfare is ended, that her iniquity is pardoned' (Is 40:1, 2). Comfort in exile is not thinkable, but God was ending the situation. He granted amnesty, which had been inconceivable before the prophetic utterance. Finding a God who is free, able and willing to bring life into the death of a nation means grace in times of a short supply of energy.

Brueggemann (2001) combines grief and hope, laments and doxologies in these words:

Jeremiah and Second Isaiah together, poets of pathos and amazement, speak in laments and doxologies. They cannot be torn from each other. Reading Jeremiah alone leaves faith in death where God finally cannot stay. And reading Second Isaiah alone leads us to imagine that we may receive comfort without tears and tearing. Clearly, only those who anguish will sing new songs. (p. 79).

3.1 Timothy 5:5 the widow who is really in need and left all alone puts her hope in God and continues night and day to pray to ask God for help.
It is clear in the prophetic books that the work is not completed until the depth of judgement, loss and grief is turned around to new possibilities. That is especially true in the words, ministry and death and resurrection of Jesus. His parables are tales of the impossible. In the tale of the Good Samaritan, a rejected person who cares for his assumed enemy is a huge surprise; in the tale of the Prodigal Son, a welcome homecoming for a disobedient son is astonishment.

The divine impossibility of exile and restoration is transposed to the life of Jesus. It is clear that, according to tradition, the death of the Messiah was regarded an impossibility. It is equally clear that the resurrection of Jesus is a re-enactment of the restoration of Jerusalem and that is surely a second impossibility. These dual impossibilities of exile and restoration, of crucifixion and resurrection, of dying with Christ and being raised with him to new life are our call to enact them (Bruggemann 2011:136). A prophetic community should be eager to recover its capacity to interpret reality, to evaluate its effects and to act consciously. The reason is that this capacity is rooted in prophetic criticism and visionary imagination that contain the strength to transform the existing order (Junler 2011:134). In a broad sense, a prophet is a person who looks at reality with the ability to interpret it from God's viewpoint. Thus, a prophet is one who speaks for someone else (Junler 2011:135).

There may also be an intermediate phase between the language to 'criticise' and 'energise' and the language of 'resistance'. It is also confrontational in a certain sense, but confrontational in a unique way, namely in using the language of deconstruction, interruption by irony, parody and even open ridicule. Prophets also use this language (cf. Is $25: 11 ; 46: 6,7)$. These kind of prophetic testimonies are:

fundamentally agents of interruption. Interruption has been their enduring hallmark, and it colors all their other multifaceted ministries. Just as Jesus, like a trickster, crosses boundaries, breaks taboos, and speaks disruptive words, so preaching fools interrupt the social and religious status quo. (Campbell \& Cilliers 2012:154)

The prophets of today also need to interrupt the status quo by unmasking and deconstructing the structures of today. The prophets are not stereotypical, strong and fearless persons, or the persons who protest loudly on platforms. Paul describes the Evangel of Jesus Christ in 1 Corinthians 1:17-25 saying, '[ $f$ ]or the foolishness of God is wiser than man's wisdom, and the weakness of God is stronger than man's strength.' To the powers of this world, the death and resurrection of Christ are the ultimate reason for ridicule. Campbell and Cilliers (2012:197) referring to Isaiah 46:5-7 and 2 Samuel 12:1-7 say that this kind of prophetic voice, 'may use parody to confront and unmask forms of iron theology, circled wagons, and closed seriousness.'

In the face of radical and continuing evil, prophetic testimony must be weeping, it must be confession, but it also must be resistance. Resistance is not just our reaction to the evil we experience and in which we participate, but it is our stand against it. It is not an act of standing still and defending 
ourselves against the evil that surrounds us, but it is moving into it, and through it, with speech and presence and action. If prophetic testimony is to be a transforming act, then the power and integrity of our proclamations, also through grief and hope, will surely be measured by their ability to mobilise communities to resist the reality that confronts us (Smith 1992:5).

What may be derived from the words and acts of the Old Testament prophets and the Prophet Jesus for the testimony of the 21st century prophets? In performing the prophetic gift, criticising and energising are two sides of the same coin. Although the toxic contamination of society (e.g. through degeneration of education and labour unrest) must be condemned in the final instance, the postponement of judgement is part of a clear pattern that can be derived from the public service of the Old Testament prophets and of Jesus. It is very important to name the problems in society and therefore to recover the capacity to interpret and evaluate reality. In pointing out the unrighteousness in society, the prophet should concentrate on the loss of both the victimised persons and the person in the position of authority. The criticism should contain pathos that bears testimony to the fact that the prophet is moved by the loss and grief of both the victimised person and the transgressor. The prophetic voice can even be a voice of grief and lament for them in their state of death. In experiencing grief accompanied by pathos, victim and transgressor will find compassion. This will focus the attention of the dying society on the grief and lament of the prophets and of God, because this toxic contamination will eventually lead to death. In very serious evils, after the persons concerned have patiently walked the path of grief and lament, it is necessary to condemn this condition of death loudly and clearly, as well as the acts of the persons who brought society into the state of death.

Only from pathos, grief and lament, and in some cases judgement as the deepest turning point, a longing for an alternative may develop. Comfort and new possibilities for rectifying injustices in society may develop from grief and lament. Only those who mourn will be comforted. The prophet's witness will be that God's newness will break the cycles of self-destruction and make new life possible. Hope is grounded in God's promises and his promises bring amazement and lead to doxology. Energising is initiated when the prophets of today point out the possibilities of hope, and hope is roused by amazement about God and his great deed of regeneration, especially in the death and resurrection of Christ. The prophetic critique focuses on selfserving and self-securing consciousness, and at the same time, the prophetic preacher will present the alternative of God's new dispensation in awe.

\section{The gift of prophecy and social involvement}

Howard (2000:66) offers a survey of the renewal of worship during the past thirty years, demonstrating a shift towards an emphasis on proclamation and social involvement. What is clear is that practising the gift of prophecy will never come into its own in a church where members attend church services only to listen to sermons. On the contrary, there should be a burning love for the revelation of God, but the members who practise the gift of prophecy should also be aware of the time, place and circumstances in which they live. Prophecy is characterised by its open attempt to actualise scripture, drawing from it concrete applications to the hearers' lives in order to bring about a reform of the human hearts. It should be based on an appeal by both preacher and community to the Holy Spirit for enlightenment, for the same Spirit dwells in the preacher and in the community, he helps both preacher and community to understand and to be moved by scripture. All homiletic preaching, therefore, includes an element of prophetic proclamation (Coyle 2006:4). The prophetic voice is not meant to be strident or negative or exclusively critical, it must rather be a positive, helpful and enlightening voice (Trautman 2008:5). Christian Liturgy is prophetic by the mere fact that it celebrates the paschal mystery of Christ. The prayers of intercession offer yet another privileged space where the prophetic facet of Liturgy is very evident (Pecklers 2008:16).

When the prophet sees the community's Sitz im Leben and hears God's word at the same time, the prophet gets caught up in an inner struggle. He or she is compelled to cry out for justice and peace, so that when he or she speaks, God is revealed and transforming action is called for. Prophets, therefore, stand as 'counter-voices' to any voice that allows the fascination with power, ambition and self-righteousness to oppose what God requires from us: to do justice, love kindness and walk humbly with God (Mi 6:8). Though they have an intimate relationship with God, their human senses consciously focus on their social, political, economic, cultural and religious context. Prophets cannot separate religious realities from human social life (Junler 2011:138).

In the context of post-apartheid South Africa, the goal of liturgy can be defined in terms of social justice and human flourishing (Barnard \& Wepener 2012:2). The social-ethical facet of liturgy is part of the kernel of Christian liturgy: the theological concept of koinonia, [community], clearly has a social facet (Barnard \& Wepener 2012:4). When a celebrating community manifests human relationships, it provides a fecund ground for the emergence and development of transformative patterns. This condition provides the foundation for a prophetic community. The context of the life of such a community is its past, its present and its vision of a better future, one in which the sufferings and the accomplishments of its own people and of those outside the community are cared for and celebrated in response to God's call. Indeed, there is an urgent need for the prophetic celebrating community to be an agent of proclamation. It has to become a prophetic voice that cries out for liberation from all kinds of situations in which human beings lose their inalienable right to their dignity and the development of their potential. The vocation and contribution of the celebrating community is to claim the opportunity for every individual, regardless of class, citizenship, race, gender, sexual 
orientation or age, to live in dignity. The individual must further be able to explore the limits of human potentialities, so that everyone can participate in establishing a new social order where freedom, justice, peace and full humanity prevail in the world (Junler 2011:134).

Today's prophetic voice takes shape in the open heart and mind of the prophet whose eyes are directed at God and whose ears are open to hear Jesus' message. Furthermore, his or her human sensitivity is empowered by the work of the Holy Spirit. His of her irrepressible passion for justice, love and peace is so contagious that other human beings soon join in the 'dance'. Prophetic self-consciousness is contagious and through it, transformation can reach gigantic proportions (Junler 2011:140). The question is therefore: Why is the 16th century prophecy not practised in the 21st century? Perhaps this is because no clear practical guidelines exist for 'how' and 'when' the gift of prophesy could be put into practice.

The regular Sunday service needs also to be seen as an opportunity for the gathering of the faith community to be nurtured and revitalised for prophetic action in and for the world. Our lives are continuing acts of worship. When the members of the prophetic community of faith gather around God's Word, they find grace to articulate their mission in harmony with the gospel of Christ they preach. Prophetic mission is directly connected with the praxis of justice. Liturgy expresses and fosters faith that does justice in missionary praxis. No prophetic mission is isolated from efforts to restructure the social-political-economic order. The justice Christians proclaim in their mission must recognise that the struggle for a just social-political-economic order parallels the struggle for the dignity of the whole human being. The theological foundation for a Christian praxis of justice is God's saving work through grace. God's acts of justice are full of love, mercy and forgiveness. These truths need to be embodied in prophetic mission (Junler 2011:142).

Smit (2004:350) states that the way people see the role of the church regarding public and social challenges inevitably depends on which form ('gestalte') of the church they regard as primary. Smit (2004) describes the characteristics of the form or identity of the church as follows:

- The church as congregation is called to worship and pray - with important implications for social needs and problems, including the formation and motivation of moral agents.

- These worshipping believers are called to join hands as members of congregations - making new kinds of joint activities and initiatives possible.

- Denominations are called to express the even fuller unity of the church ecumenically - allowing attempts to address the more widespread and fundamental roots of the social problems, as well as to play advocacy roles on behalf of the voiceless.

- In the last resort, the church consists of individual believers, the salt of the earth, who are called to follow Jesus - practicing the Christian life in all aspects of the public sphere, politically, economically, civil society, everywhere. (pp. 355-360)

Taken together, these different emphases provide a fuller picture of what the liturgical role and calling of the church on society could be.

A prophetic liturgy involves acquaintance with the practical facets of the celebrating community, that is, the subjective spiritual world is not disconnected from the concrete world in which people live every day. In other words, the prophetic understanding and praxis of liturgy facilitate the community's awareness of its presence in the world: 'Ubi caritas et amor, Deus ibi' (Junler 2011:142).

The ministry of the Word is dedicated to the entire congregation and every member has the responsibility to contribute, because everyone should eagerly desire the gift of prophesy (1 Cor 14:1). It is important to explain constantly to the members of the congregation that there is little value in only listening to the Word of God and not doing what the Word asks of them. A confessing response must follow on the Word service. Practically, it means that every member should develop the gift of prophecy, which is to apply God's Word to different situations of life. ${ }^{4}$

\section{Application of prophetic testimony to education and labour unrest Focus on education}

Education is a fundamental human right and it has an effect on democracy and political stability. In South Africa, education is in serious trouble.

'Poor education lies at the root of most of South Africa's problems, including unemployment, poverty and inequality. Education is a debt that the present generation owes to future generations', the FW de Klerk Foundation (2012) said in a statement. The World Economic Forum, according to the Foundation, ranked South Africa's education system 133rd out of 142 countries in the world.

Our schoolchildren fare very badly in Grade 3 and Grade 6 numeracy and literacy tests. Perhaps the most damning statistics presented by the National Planning Commission are that teachers in Black schools teach an average of only 3.5 hours a day, compared with 6.5 hours a day in former White

\footnotetext{
4.Therefore, opportunities have to be created for 'sermon discussion'. This discussion Therefore, opportunities have to be created for 'sermon discussion'. This discussion
should deal in particular with the scripture reading, aspects that perhaps could should deal in particular with the scripture reading, aspects that perhaps could
not have been touched on in the sermon, drawing lines to practical life and the manner of the practical application of what God has said to the congregation. The agreement should be the following: we are using the gift of applying the Word of God concretely, and therefore members are now going to work together to draw lines from God's Word to situations in everyday life (Kim 2006:149). To give the congregation the opportunity to boldly apply the gift of prophecy, the preacher may make the scripture passage and the sermon available to about three members, prior the start of the service. Ideally, the three members must represent different generations, professions and age groups. The opportunity may be given to a woman from the business world, a female student and a male construction worker to apply from the business world, a female student and a male construction worker to apply the sermon and scripture passage to their particular living situations. In this way, other members will also develop confidence to do the same. For four to six weeks, this method could be followed with other members. Probably the result would be that members at their homes and work would start to apply the preached word in their own lives and work environments. Thereafter, members will perhaps be able to bring the ritual of the gift of prophecy into practice more spontaneously, also in the gathering of the congregation.
} 
schools. In an interview with Van der Berg and Spraull, it was said that, measured by international benchmarks almost $80 \%$ of Grade 5 learners are judged to be at 'serious risk of not learning to read.' Sixty per cent leave school without matric and a lot of those who pass matric do so with an average mark of less than $40 \%$. Even if one compares South Africa with mainly low-income countries in Africa, we still perform poorly (SA education 2011:3).

Education in South Africa at the end of the apartheid era was characterised by large-scale inequalities in the provision of services. Racial segregation and inequality persisted in the administration of education, the provision of schooling, nonformal education and the organisation of higher education and training (November, Alexander \& Van Wyk 2010:787). Although racial segregation has been abolished for 18 years now, schools that served predominantly White students under apartheid have remained functional, but those that served Black students have remained dysfunctional and have been unable to impart the necessary numeracy and literacy skills students should acquire at this level (Spaull 2012:1). This has led to massive demoralisation and disillusionment among teachers and a negative and worsening perception of the teaching profession (McGrath \& Akoojee 2007:431).

The current international orthodoxy of globalisation emphasises skills as a central element of sustainable economic, social and political systems at the national and regional level. In the globalisation account, national economic success is largely dependent on the ability to create, attract and deploy human capital more effectively than competitor nations or regions. Skills and knowledge help build international competitiveness, employment and prosperity. Thus, education is widely seen as a key policy tool of the globalisation era (McGrath \& Akoojee 2009:149).

It is easy to blame the central and provincial governments for the injustice inflicted on children by the poor rendering of service in education. The prophetic voice in the worship service and after the gathering of the congregation ought to be heard clearly with regard to the situation of education in our society. The prophetic testimony will definitely criticise the present situation. In this article, not every aspect of this testimony can be discussed. Children are the most affected group and therefore the focus must be on them. They need a voice on their behalf to express the losses they experience: loss of developing their God-given skills, loss of shaping their personalities and inner qualities and loss of opportunities that perhaps would have come to them in future. The pathos with these children by today's prophets will be seen in their grief for the affected children. In worship services and in the lives of Christians, the grief will be experienced in sincere laments. This would also include the teachers who on the one hand fail to deliver proper education because of poor training, and on the other hand fail because of their own irresponsibility towards their calling. Grief will include confession of sinful actions and the worship community will assume co-responsibility for those sins because of many factors, including the fact that they are part of the same society. Although we know that resistance and judgment are postponed, both actions will be brought into force according to the seriousness of the evil.

The prophetic testimony will also stress an alternative for the loss of and grief for education. Jesus' attitude towards children and his concern and love for children in several places in the Bible present an alternative viewpoint on the education of children. It was an amazing feature of society in biblical times and the dream of an alternative vision that the gift and appreciation of children would give hope for a new attitude towards and vision of education. The prophetic testimony may activate the imagination of all the people who are involved in education. The gift of teachers to be involved in shaping the personalities and skills of children is an amazing gift. Embracing this alternative view - instead of supporting the current one that regards children as instruments to gain a salary - will certainly give hope and will energise the system from the bottom to the top. This is also an alternative to the present viewpoint that education will improve if the top structures of the government will change their attitude and input in education.

\section{Labour unrest}

South Africa has the worst labour relations in the world. According to the World Economic Forum's Global Competitiveness Report, of the 144 countries assessed in terms of co-operation in labour-employer relations, South Africa fares the worst (De Klerk 2012a). On top of this finding, the Marikana massacre took place on 16 August 2012. A wave of violent and uncontrolled wildcat strikes followed and hopelessly unrealistic wages were demanded (De Klerk 2012b). City Press, a South African newspaper, used the banner headline 'Strike Nation' to describe the crisis. The wildcat strikes are inflicting heavy damages on some of the world's biggest gold and platinum producers in a country that remains Africa's economic powerhouse (York 2012:3). Indeed, mining drives the economy of South Africa, which is still one of the world's dominant producers of platinum, gold and chromium. In September, President Jacob Zuma said the strikes had already cost the nation about R4.5 billion (nearly \$563 million).

It must be remembered that Black miners have received low salaries for a long time and face poor living conditions in shantytowns that are often beset by alcoholism, drug abuse and prostitution. The same goes for salaries of day labourers who work in agriculture in South Africa, another major part of the nation's economy (Gambrell 2012:5). With two major South African industries (mining and farming) paralysed by unrest and violence, some officials fear that the strikes could undermine the economy and could destabilise a nation already fractured by severe racial and economic chasms. The violence and illegal strikes have shaken South Africa's reputation and exposed its persistent inequalities. Eighteen years after the end of apartheid, it remains one of the most unequal countries in the world, with widespread poverty 
and unemployment in a country where most White people still have comfortable incomes. South Africa could be facing disastrous economic consequences from the strikes, analysts warn. Its currency, the rand, has suffered its worst weekly decline in more than a year.

The comprehensiveness of the strikes evokes a kind of impulsive reaction of wrath and a voice of condemnation. In what way should the prophetic voice differ from the above-mentioned one? The evildoers of killing people and destroying the property of employers and the public should be named, and the prophetic testimony of resistance and disapproval must be heard. The prophetic criticism goes deeper. It affects the labourers, employers and the unions. The pathos towards the labourers involves grief for their meagre income, poor housing, living conditions and poverty, but also for their responsibility, or lack of responsibility, and the pressure they experience from unions, whether or not they are members of a specific union. The prophetic voice may express the losses of the workers in many facets of their lives. The testimony of partaking in their grief may be voiced in worship services, but also in gatherings organised by local churches and different denominations. In this way, a door could be opened to the hearts of workers and solidarity with them in their need could be shown. On the other hand, the prophetic voice will also be involved with the employers. Grief will be experienced for the loss of property and income, but especially for the loss of good relationships. The grief must also be for employers who exploit workers and enrich themselves at the cost of others. The combined grief for and the laments on the losses of both workers and employers will open the possibility of new life and new relationships after workers and employers have mourned the dying relationships caused by labour unrest.

The prophetic testimony cannot ignore the role of the unions in labour unrest. The unions also experience losses - in membership, in credibility in the eyes of the public and in mutual clashes. Although it will be difficult to give prophetic testimony through grief and lament for Christians who were never exposed to unions and their internal politics, it is their calling to grieve on behalf of unions, not only because of their so-called losses, but also because their sins affect the society and have to be confessed. That is the only way that sin can be brought to death before God.

For both the workers and the employers there is an opportunity of a new way of handling labour questions. Many examples are found in the life of Jesus and in the writings of Paul. The death and resurrection of Jesus is the basis for revitalising labour relations. This event is the turning point in history and will always bring amazement. This amazement will create hope, and this hope will energise the process of reconciliation. The death and resurrection of Christ is the final proof of his preaching that every person must consider others better than him- or herself. Whoever wants to become great in the Lord's eyes must be the servant of others. This is the alternative viewpoint of today's prophet.

\section{Conclusion}

In the science of liturgy attention must be given to the revitalisation of the gift of prophesy. The possibility of rendering service through prophetic testimony as a liturgical act in the South African society is wide open. Prophetic testimony serves to criticise the dominant perception in order to dismantle it, but is also serves to energise persons and communities by its promise of another time and situation towards which the community of faith could move.

\section{Acknowledgements Competing interests}

The author declares that he has no financial or personal relationship(s) which may have inappropriately influenced him in writing this article.

\section{References}

Barnard, M. \& Wepener, C., 2012, 'Reclaiming space for learning in liturgical contexts: Cracks in the maxim of the uselessness of liturgical ritual', HTS Teologiese Studies/ Theological Studies 68(2), Art. \#1184, 8 pages. http://dx.doi.org/10.4102/hts. v68i2.1184

Brueggemann, W., 2001, Prophetic imagination, Minneapolis, Fortress Press.

Brueggemann, W., 2011, The practice of prophetic imagination: Preaching an emancipating word, Fortress, Augsburg. (Kindle Edition).

Calvin, J., 1965, Harmony of the evangelists, Matthew, Mark and Luke', vol. 3 Eerdmans, Grand Rapids.

Campbell, C.L. \& Cilliers, J.J., 2012, Preaching fools: The gospel as a rhetoric of folly, Baylor University Press, Waco.

Coyle, J.K., 2006, 'From homily to sermon to homily: The content of Christian liturgical preaching in historical perspective', Liturgical Ministry 15, 1-9.

Cranfield, C.E.B., 2004, Romans 9-16: A critical and exegetical commentary, T\&T Clark International, London.

De Boer, E.A., 2004, 'The presence and participation of lay people in the Congrégations of the Company of Pastors in Geneva', The Sixteenth Century Journal 35(3), 651670. http://dx.doi.org/10.2307/20477039

De Klerk, F.W., 2012a, 'Current developments in South Africa and the international Community', Speech by F.W. de Klerk at a joint dinner: Northwest University and Greenwich School of Theology, London, viewed 03 October 2012, from http://www.fwdeklerk.org/cgi-bin/giga.cgi?cmd=cause_dir_news_item\&cause_ id $=2137 \&$ news_id $=115923 \&$ cat_id $=1595$

De Klerk, F.W., 2012b, 'South Africa: 1994, 2012 and 2020', Speech by F.W. de Klerk delivered in Johannesburg 31 October 2012, from http://www.fwdeklerk.org/ cause_data/images/2137/Johannesburg_SPEECH.pdf

Du Toit, J.D., 1977, Totius versamelde werke, deel 6, Tafelberg, Kaapstad.

Ellison, J., 2012, 'Labor unrest on South African farms', Farm Plus Staff Writer, 15 November, p. 2.

Farnell, F.D., 1992, 'Is the fift of prophecy for today? Part 1, The current debate about New Testament prophecy', Bibliotheca Sacra, July - September, 277-303.

FW de Klerk Foundation, 2012, 'Our education system is in crisis', Independent Newspapers, 02 August, viewed, n.d., from http://www.iol.co.za/news/southafrica/our-education-system-is-in-crisis-1.1355362

Gambrell, J., 2012, 'Labor unrest in South Africa expands to farms as grinding strikes at mines ease', Fox News, 14 November, viewed n.d., from http://www.foxnews. com/world/2012/11/14/strikes-in-mines-and-now-agriculture-keep-grindinggrip-on-south-africa/

Green, G.L., 2002, The letters to the Corinthians, Apollos, Leicester.

Hall, D.R., 2003, The unity of the Corinthian correspondence, T\&T Clark International London.

Harold, G., 2003, "Is there a place for "prophetic" utterances in public worship? A dialogue with W. Grudem', The South African Baptist Journal of Theology 4, 168-183.

Howard, R.R., 2000, Review of Preaching in the Context of Worship, D.M. Greenhaw \& R.J. Allen (eds.), Lexington Theological Quarterly 3, 63-67.

Junler, T.B., 2011, 'Foundational concepts for prophetic liturgical praxis', Encounter 72(1), 133-144.

Kim, C.H., 2006, 'Prophetic preaching as social preaching', Evangelical review of theology 30(2), 141-151.

McCord, A. \& Bhorat, H., 2003, 'Employment and labour market trends in South Africa', in Human Resources Development Review 2003: Education and skills in South Africa, pp. 112-141, HSRC Press, Cape Town.

McGrath, S. \& Akoojee, S., 2007, 'Education and skills for development in South Africa: Reflections on the accelerated and shared growth initiative for South Africa',
International Journal of Educational Development 27, 421-434. http://dx.doi. org/10.1016/j.ijedudev.2006.07.009 
McGrath, S. \& Akoojee, S., 2009, 'Vocational education and training for sustainability in South Africa: The role of public and private provision', International Journal
of Educational Development 29, 149-156. http://dx.doi.org/10.1016/j.ijedudev. of Education

November, I., Alexander, G. \& Van Wyk, M.M., 2010, 'Do principal-educators have the ability to transform schools?: A South African perspective', Teaching and Teacher Education 26, 786-795. http://dx.doi.org/10.1016/j.tate.2009.10.014

Pecklers, K.F., 2008, '”Is Liturgy Truly Being Prophetic?"', Liturgical Ministry 18, 14-18.

'SA education: The poorest choice', Mail and Guardian, 08 April, 2011, pp. 4-5.

Smit, D.J., 2004, 'Oor die kerk en maatskaplike uitdagings in ons land', Nederduitse Gereformeerde Teologiese Tydskrif 45(2), 350-362.
Smith, C.M., 1992, Preaching as weeping, confession, and resistance: Radical responses to radical evil, John Knox Press Louisville.

Spaull, N., 2012, 'Poverty \& privilege: Primary school inequality in South Africa', International Journal of Educational Development, 1-12. http://dx.doi.org/ 10.1016/j.ijedudev.2012.09.009

Trautman, D.W., 2008, 'When should liturgists be a prophetic voice?', Liturgical Ministry 17, 1-5.

Wright, R.W. \& Strawn, B.D., 2010, 'Grief, hope, and prophetic imagination: Psychoanalysis and Christian tradition in dialogue', Journal of Psychology and Christianity 29(2), 149-157.

York, G., 2012, 'South Africa's ruling party paralyzed as strikes choke off economy', The Globe and Mail, 30 September, p. 3. 